\title{
'n Vergelykende studie tussen 'n gedeelte uit die Samaritaanse Liturgie en verwante gedeeltes in die Pentateug
}

J Beyers \& A P B Breytenbach

Universiteit van Pretoria

\begin{abstract}
A Comparison between an excerpt from the Samaritan Liturgy and corresponding texts in the Pentateuch

The text of the Samaritan Liturgy is almost unknown among scholars of the Old Testament. The value of the Samaritan Liturgy lies in its correspondence with the Old Testament. The way in which the Samaritan Liturgy makes use of the Old Testament texts brings to mind the question, 'What is the relationship between the Samaritan Liturgy and the Old Testament?' This article discusses a randomly chosen prayer in the Samaritan Liturgy. The prayer is analysed in terms of its relatedness to corresponding Old Testament texts. This study tries to point out that the text of the Samaritan Liturgy can be helpful when studying Old Testament traditions.
\end{abstract}

\section{VRAAGSTELLING}

Die Samaritaanse Liturgie is 'n onontginde terrein. Montgomery (1968:297) wys daarop dat Gesenius, Cowley en Heidenheim die eerstes was wat baanbrekerswerk op die terrein gedoen het. Brown het ook 'n waardevolle bydrae gelewer met sy ongepubliseerde navorsing oor 'n klein deel van die Liturgie. In Suid-Afrika is daar nog niks oor die onderwerp gepubliseer nie.

Die navorsingsresultate wat hier volg, verteenwoordig dus slegs die eerste treë op die terrein van die studie van die Samaritaanse Liturgie. In hierdie studie word slegs 'n enkele gebed uit die Liturgie vertaal en alleen die verwantskappe van die gebed met die Masoretiese Pentateug word bespreek.

* Hierdie artikel is gebaseer op 'n skripsie wat ingedien en aanvaar is as deel van die vereistes vir die BD-graad (1994), Departement Ou-Testamentiese Wetenskap, Fakulteit Teologie (Afd A), Universiteit van Pretoria, onder leiding van prof dr A P B Breytenbach. 
Sodoende word gewys op 'n literêre verwantskap tussen die Samaritaanse Liturgie en Masoretiese Pentateug (kyk 3.1 vir 'n bespreking van die verband tussen die Masoretiese en Samaritaanse Pentateug).

\section{ONTSTAAN EN GESKIEDENIS VAN DIE SAMARITANE}

Montgomery (1968:48) is 'n eksponent van die tradisionele teorie, naamlik dat inligting aangaande die oorsprong van die Samaritane gesoek moet word in die tydperk vanaf die Assiriese verowering van Israel in 722 v C. Montgomery (1968:ix) se standpunt is dat die Samaritane as religieuse groep 'n Joodse sekte is wat tot stand gekom het in ongeveer 350 v C. Hy glo dat die finale breuk tussen die Jode en Samaritane die bou van die tempel op die berg Gerisim was. Hy maak nie 'n keuse oor die vraag of die ontstaan van die Samaritane as 'n eenmalige gebeurtenis of as ' $n$ langdurige proses gesien moet word nie.

Ou-Testamentiese gegewens (2 Kon 17) dui volgens Montgomery op die ontstaan van die Samaritane. Die gedeelte staan binne die konteks van die Assiriese verowering van Israel. Montgomery (1968:53) wys daarop dat die hele Noordryk nie weggevoer is in ballingskap nie en dat almal nie omgekom het in die oorlog nie. Die bevolking van die streek het dus grotendeels bestaan uit plaaslike, agtergeblewe Israeliete. Die Assiriese immigrante in Israel het mettertyd die godsdiens van Israel begin beoefen. Die Assiriese immigrante en Israeliete het ondertrou en die nuwe geslag het bekend gestaan as die Samaritane. Die godsdiens van die Samaritane was dus aanvanklik 'n sinkretistiese godsdiens. Die godsdiens van Israel het later oorheersend geword. Die Samaritane is daarom niks anders as 'n Joodse sekte nie (Montgomery 1968:54).

Brindle (1984:48 e v) stel dat daar vier teorieë oor die ontstaan van die Samaritane geïdentifiseer kan word:

* Die Samaritane se eie weergawe: Hulle glo dat hulle die voortsetting van die ou Israelitiese geloof is soos dit in die pre-monargale tyd by Sigem bestaan het.

* Die Jode se weergawe: Hulle glo dat die Samaritane op 'n dwaalweg is en dat hulle Jahwe volgens hulle eie goeddunke aanbid. Die ontstaan van hierdie dwaling word na die Assiriese oorname van die Noordryk teruggevoer (722 v C).

* 'n Interpretasie op grond van die gegewens in Esra-Nehemia: Volgens hierdie interpretasie het die Samaritane in die Persiese tyd van die Judaïsme weggebreek. Die terugkerende Judeërs het onder leiding van Esra, en later Nehemia, die Noorde se hulp om die tempel in Jerusalem te help herbou, van die hand gewys. 
* Die gebeure rondom die tempel op Gerisim: Volgens hierdie interpretasie skeur die Samaritane eers in die Griekse periode weg van die Judaïsme. In dié tyd word die tempel op Gerisim gebou. Die Gerisim-tempel word dan die finale rede vir die skeuring tussen die Judeërs en die Samaritane.

Brindle (1984:75) huldig die standpunt dat die ontstaan van die Samaritane 'n proses was wat begin het by die skeiding tussen die Noord- en Suidryk. Die voortdurende proses het 'n paar uitstaande momente, naamlik die invoer van vreemde koloniste in Samaria deur die Assiriërs, die Judeërs se verwerping van die Samaritane, die bou van die Samaritaanse tempel op die berg Gerisim en Johannes Hirkanus se verwoesting van die Samaritaanse stad Sigem en die tempel op Gerisim (tweede eeu v C). Brindle versoen dus die vier teorieë deur te sê dat daar geen rede bestaan om 'n enkele gebeurtenis te kies as die enigste oorsaak vir die ontstaan van die Samaritane nie.

Venter (1989:123) en Coggins (1968:42) wys daarop dat die Ou Testament (2 Kon 17) 'n oorvereenvoudigde en subjektiewe weergawe van die ontstaan van die Samaritane gee. Coggins (1968:43) glo dat die oorsprong van die Samaritane gesoek moet word by die politieke verdeeldheid tussen die Noord- en Suidryk. Volgens hom word die Samaritane eers in die tweede of eerste eeu $v$ C 'n selfstandige religieuse groep (1968:46). Coggins (1968:46) het deur middel van 'n redaksie-kritiese ondersoek van 2 Konings 17 aangedui dat dié verwysing na die Samaritane nie anti-Samaritaanse propaganda is nie, maar polemies van aard is, naamlik om die eenheid van die Judaïsme onder die gesag van Jerusalem te behou. Die Ou Testament help ons dus nie veel ten opsigte van die ontstaan van die Samaritane nie.

$\mathrm{Na}$ my mening word die wortels van die ontstaan van die Samaritane nie ver genoeg terug in die geskiedenis gesoek nie. Coggins (1968:43) maak wel die opmerking dat die oorsprong van die Samaritane eerder gesoek moet word in die politieke verdeeldheid wat van vroeg af tussen die Noorde en Suide bestaan het. Venter (1989:125) glo dat die spanninge tussen die Noorde en Suide as faktore gesien kan word wat later aanleiding gegee het tot die ontstaan van die Samaritane. Nie een van die outeurs na wie verwys is, dui die oorsaak van die spanning aan nie. Die spanning tussen die Noorde en Suide kan teruggevoer word na die vroegste bestaan van die volk. Iets van hierdie spanning word gereflekteer in die vertelling oor die aartsvaders.

Die seuns van Jakob het die stamme van Israel geword. Die Noorde, wat onder leiding van die stam van Josef gestaan het, het net soos die Suide, wat onder leiding van Juda gestaan het, voortdurend daarop aanspraak gemaak dat húlle die ware opvolgers van Jakob is. Die ware opvolgers van Jakob sou die godsdiens van die volk bepaal. In die seënspreuke van Jakob in Genesis 49 ('n Judese tradisie) en die 
seënspreuke van Moses in Deuteronomium 33 ('n Noord-Israelitiese tradisie), word aan Josef groter gesag en voorspoed toegesê as aan sy broers. Dit dui op die belangrikheid van die Josefstam (Wintermute 1989:986).

Die stelling dat Israel onder leiding van Jerobeam weggeskeur het van Juda moet gesien word as 'n interpretasie deur die Suide om die Noorde se kredietwaardigheid as draer van die ortodokse geloof, af te breek. Die spanning tussen Noord en Suid wat volgens die vertelling al by die seuns van Jakob teenwoordig was, het oor die loop van eeue aanleiding gegee tot die ontstaan van die Samaritane. Die Samaritane is dan nie 'n Joodse sekte nie, maar eerder 'n voortsetting van die godsdienstradisie soos dit in die Noorde oorgelewer is.

Daar moet voortdurend in gedagte gehou word dat die geskiedskrywing van Israel, Juda en die Samaritane so geskryf is dat elke groep hulleself as die ortodokse groep voorhou en die opponente as aanhangers van 'n dwaalleer.

\section{DIE LITERATUUR VAN DIE SAMARITANE}

Die Samaritane was 'n gemeenskap wat 'n magdom religieuse literatuur gelewer het. Bowman (1977:i) sê tereg dat alle Samaritaanse literatuur religieuse literatuur is. Die historiese werke is geskryf om die bestaan van die religieuse gemeenskap te regverdig. In hierdie studie is daar slegs ruimte om 'n oorsig van die verskillende soorte Samaritaanse literatuur te gee. Die Samaritaanse Liturgie is slegs 'n enkele voorbeeld van die literatuur. Die volgende soorte literatuur kan geïdentifiseer word:

\subsection{Die Samaritaanse Pentateug}

Die mees aanvaarbare hipotese is dat die Samaritaanse Pentateug uit 'n ouer en ander tekstradisie as die Masoretiese Pentateug kom.

Die Samaritane het 'n paar opsetlike teologiese veranderinge in die teks aangebring. Die veranderinge is gemaak om die belangrikheid van Gerisim bo Jerusalem as aanbiddingsplek aan te dui (Montgomery 1968:xii, xiii).

Die tekstradisie van die Samaritaanse Pentateug het in die vyfde tot tweede eeu v C ontwikkel as 'n proto-Samaritaanse teks en eers in die Hasmoniese tyd sy finale beslag gekry. Die Masoretiese tekstradisie stam uit Babilonië. Die Samaritaanse Pentateug is dus ' $n$ voorbeeld van ' $n$ tekstradisie wat in Palestina tydens die Hasmoniese tyd bestaan het (Brindle 1984:74):

\subsection{Die Samaritaanse Kronieke}

Daar bestaan vier geskiedenisbronne van die Samaritane. 
* Die Taulida is 'n werk wat in Hebreeus geskryf is en wat handel oor die geskiedenis van die Samaritane en Jode. Dit is geskryf in 1149 deur Eleaser, 'n seun van die hoëpriester Amram.

* Die Boek van Josua is 'n Arabiese werk wat geskryf is in die Samaritaanse skrifsisteem. Dit dateer uit 1362. Dit handel oor die geskiedenis sedert Moses en Josua. Dit bevat ook 'n aantal legendes afkomstig uit onbekende bronne.

* Die Kroniekboek van Abu'l Fath is 'n Arabiese werk wat waarskynlik die mees objektiewe weergawe van die geskiedenis van die Samaritane bevat. Hy skryf in ongeveer 1355. Die werk begin by Adam en eindig met die oorname deur die Islam (756 n C).

* Die Kroniekboek Adler is in Hebreeus geskryf. Die Kroniekboek Adler en die Boek van Josua blameer Eli vir die breuk tussen die Jode en Samaritane. Die Samaritaanse Kronieke gee op die oog af die geskiedenis op 'n subjektiewe wyse weer, om daarmee die aanspraak te bevestig dat die Samaritane die ware Israel is.

\subsection{Samaritaanse Bybelkommentare}

Marka kan as die grootste Samaritaanse teoloog van alle tye gereken word (Montgomery 1968:204). Hy het in die vierde eeu 'n monumentale teologiese werk gelewer waarin temas uit die Pentateug bespreek word. Die werk is in Aramees geskryf. Die teologie van Marka is beïnvloed deur die Kabbala (die Joodse Gnostiek), deur apokriewe werke van die Jode en deur ander godsdienste soos die Mandeërs.

\subsection{Die Samaritaanse Targoems en Talmoed}

Die Samaritane het dele uit die Pentateug in Aramees vertaal. Sodoende het 'n aparte Targoemliteratuur ontstaan. Die Targoems is oor die eeue verwring deur verkeerde vertalings en as gevolg van oorskryffoute deur kopieerders wat nie Aramees goed geken het nie. Die gevolg is dat die taal moeilik verstaanbaar geword het. Van die Targoems het ooreenkomste met die LXX. Sommige Targoems vertoon dieselfde styl as die Rabbynse Targoem Onkelos. Die ooreenkomste is as gevolg van latere hersienings van die Samaritaanse Targoems waartydens invoegings gemaak is (Montgomery 1968:290).

Soos die Karaiete ('n Joodse sekte) het die Samaritane geglo dat hulle streng volgens die Tora-wette moet leef. Met verloop van tyd was dit in die praktyk nie meer moontlik nie en moes daar nuwe interpretasies gegee word aan die wette. So het 'n Samaritaanse Talmoed ook ontstaan. 


\subsection{Die Samaritaanse Liturgie}

Die Liturgie bevat voorskrifte vir die handelinge en inhoude van die religieuse aktiwiteite tydens die religieuse byeenkomste. Die Liturgie sorg vir die ordelike verloop van die religieuse byeenkomste.

Brown (1966:vi) wys daarop dat die oorsprong van die Samaritaanse Liturgie baie vaag is. Dit kan aanvaar word dat die Samaritane vanaf die vroegste tye samestellings uit gepaste Pentateugpassasies gebruik het as gebede. Die Pentateugpassasies het gedien as inleiding- of slotformules by die offergeleenthede (Brown 1966:vi). Dié passasies het as basis gedien vir latere byvoegings. Die byvoegings kon hulle oorsprong gehad het by ander Joodse groepe, soos byvoorbeeld die Sadokiete (Brown 1966:vii).

Heidenheim (1971:ix) verdeel die Samaritaanse Liturgie in verskillende soorte tekste, naamlik: perikope, himnes, gebede en litanieë. Montgomery (1968:298) wys op die verskillende soorte himnes. Daar is himnes wat saamgestel is uit aaneengerygde Ou-Testamentiese verse met dieselfde tema. Heidenheim noem die verskynsel kazin (1971:xxvi). Ander himnes is gebede in prosavorm. Himnes wat as shiroth bekend staan, bestaan uit kort lofredes aan God of lang, uitgerekte Midrash-tipe samestellings wat bedoel is om geresiteer te word op feesdae of op die Sabbatdag. Baie daarvan is akrostikons. Litanieë is 'n reeks gebede wat deur 'n priester voorgelees word. Die voorlesing word afgewissel met 'n kort antwoord deur die gemeente of koor. Cowley se indeling van die Liturgie, te wete tussen die Defter en liturgieë, is baie waardevol (Montgomery 1968:298).

\subsubsection{Die Defter}

Die Defter (via Arabies van die Grieks $\delta \iota \phi \theta \varepsilon \rho \alpha$ wat 'boek' beteken) bestaan uit saamgestelde eenhede, gebede en himnes wat geskryf is deur Marka en Amram Dara. Dit is die oudste laag (vierde eeu) van die Liturgie en bepaal die gees van die res van die Liturgie. Dit is geskryf in Samaritaans-Aramees. Amram se werk word die Durran genoem en is hoofsaaklik in prosa geskryf. Die liturgieë word vir daaglikse godsdienspraktyke en op die Sabbatdag gebruik (Brown 1966:ix). Die Defter is tydens liturgiese herlewings in die elfde en veertiende eeue uitgebrei (Brown 1966:x).

\subsubsection{Liturgieë}

Liturgieë is vir die dienste van die Eerste maand, vir Pinkstertyd, vir die Sewende maand en vir besnydenisse, huwelike en begrafnisse gebruik.

\section{DIE TAAL VAN DIE SAMARITANE}

Heidenheim (1971:viii) maak 'n indeling van die Liturgie volgens die taal waarin die tekste geskryf is. Die Liturgiese tekste is geskryf in Hebreeus, die moedertaal van die 
Samaritane. Dit is ook in nuwe-Hebreeus ('n term wat Heidenheim gebruik vir die Hebreeus wat ooreenstem met die na-eksiliese Hebreeus en Mishna-Hebreeus) geskryf. Verder is Samaritaans-Aramees ook gebruik. In die laaste paar eeue voor die Christelike jaartelling, het Aramees die algemene spreektaal van die Midde-Ooste geword. Hebreeus het die religieuse taal gebly totdat Aramees dit mettergaan vervang het. Eers in die veertiende eeu het Hebreeus weer Aramees verdring. Die Aramees wat die Samaritane gebruik, is verwant aan Galilese Aramees. Daar kan dus nie van 'n aparte Aramese dialek gepraat word nie. Gaster (1962:196) is van mening dat van die Samaritaanse literatuur geskryf is in 'n Wes-Aramese dialek. Die ontstaanstyd van die Liturgie kan ingedeel word in verskillende periodes (Heidenheim 1971:xiii):

\subsection{Die eerste periode (tot met die opkoms van die Christendom)}

Die Samaritane en Sadduseërs uit hierdie periode deel sommige teologiese standpunte. Albei groepe het slegs die Pentateug gebruik. In die vroeë periode word teologiese temas uit die Pentateug gebruik in die Liturgie.

Die kazin-tekste (kyk 2.5; Brown 1966:xxi noem dit ketaf-tekste) dateer uit hierdie periode. Dit maak 'n groot deel uit van die Liturgie. Die aaneengerygde verse uit die Pentateug het die funksie om die volk te onderrig. Die verse is ook as bewys-stukke vir teologiese stellings aangevoer (Brown 1966:xx).

\subsection{Die tweede periode (eerste tot sesde eeu $\mathrm{n} \mathrm{C}$ )}

In dié tydperk begin die Christelike invloed die Sadduseër-denke in die Samaritaanse godsdiens verdring. Heelwat Samaritane het hulle tot die Christendom bekeer. Die inhoud van die Liturgie weerspieël dié Christelike invloed.

Die tekste uit hierdie periode is hoofsaaklik in Samaritaans-Aramees geskryf. Die gnostiese invloed op die Samaritaanse denke het ook neerslag gevind in die Liturgie. 'n Aantal van die Godsname in die Liturgie is afkomstig uit die Gnostiek, byvoorbeeld קצים wat 'die Een wat staan' beteken.

\subsection{Die derde periode (sewende tot vyftiende eeu)}

In dié periode is die taal van die Liturgie na-Bybelse Hebreeus. Die meeste van die shiroth en himnes dateer uit hierdie periode. Die Islam het onvermydelik invloed op die Samaritaanse denke en gevolglik op die Liturgie gehad. Die Islam-oorheersing het die opstellers van die Liturgie genoodsaak om in Arabies te begin skryf, aangesien die voertaal van die Samaritane in dié stadium Arabies was. Die Pentateug wat in 'n groot mate die bron van die Liturgie was, is in Hebreeus oorgelewer. Die opstellers van die 
Liturgie moes nou 'n plan beraam om die beelde van die Hebreeuse Pentateug in Arabies oor te lewer. Die gevolg was dat nuwe woordeskat en uitdrukkings geskep is. In Samaritaanse kringe is die nuwe skeppings ongekontroleerd oorgelewer. Foutiewe spelling van woorde het fonetiese foute laat insluip. Die 'foutiewe' woorde het later aanvaarbaar geword en is in die bepaalde vorm oorgelewer. Samaritaanse Arabies is dus vol Aramaïsmes en Hebraïsmes.

Cowley (1909:xxxiv) wys daarop dat die taal van die Samaritaanse Liturgie soos volg uiteengesit kan word. In die vierde eeu $\mathrm{n} \mathrm{C}$ is Aramees die taal waarin die Liturgie geskryf is. Vanaf die sewende eeu het Arabies vinnig gegroei tot die algemene voertaal en kennis van Aramees en Hebreeus het begin kwyn. Gedurende die tiende tot elfde eeu is Aramees nie meer die spreektaal van die Samaritane nie, maar word 'n Aramees wat met Hebreeus vermeng was, gebruik om die Liturgie te skryf. In die veertiende eeu word ' $n$ Hebreeuse mengvorm met Aramees gebruik as liturgiese taal.

Heidenheim (1971:viii, ix) stel dat die Samaritaanse taal nie 'n vermenging van verskillende tale is nie, maar ' $n$ taal met sy eiesoortige grammatika. Net soos die Mishna, Targoem en Talmoed sy eiesoortige grammatika het, het die Samaritaanse Liturgie ook sy eie grammatika.

Dit is duidelik uit die verklaring wat Cowley (1909:xxxiv, xxxv) gee, dat die Samaritaanse taal oor eeue gegroei en verander het. Invloede van ander tale op die Samaritaanse taal kan nie geignoreer word nie. Die oorsprong van sekere grammatikale vorme kan verklaar word na aanleiding van ' $n$ ander taal wat 'n invloed op die Samaritane se taal gehad het.

\section{5. 'N FEESGEBED UIT DIE LITURGIE}

Die teks wat gekies is om vertaal te word, is ' $n$ feesgebed. Die opskrif van dié teks dui aan dat dit 'n gebed uit die liturgie van die fees tydens die agste maand of dag is.

Uit die opskrif van die gebed kan ons aflei dat die samesteller van die gebed $A b d$ Allah Ben Shelomoh is. Ben Shelomoh word deur Heidenheim (1971:xi) aangegee as 'n outeur van die na-Bybelse Hebreeuse Liturgie. Cowley (1909:xxxiv) kwalifiseer die taal uit die tydperk waarin Ben Shelomoh skryf, as 'n mengvorm van Hebreeus en Aramees:

Die vertaling wat volg, is nóg ' $n$ dinamiese nóg ' $n$ teksgebonde vertaling. Daar is met dié vertaling gepoog om hierdie gebed verstaanbaar in Afrikaans weer te gee. Die teks-edisie van Cowley (1909:782-783) word as basisteks vir die vertaling gebruik: 


\section{VERTALING}

Gebede van die fees van die agste dag/maand:

Verder word die himnes uit die spreuke van die oorlede oom voorgedra, die wyse man van kennis, die vroom geleerde, Abd Allah Ben Shelomoh (Salomo), die sterke.
A a Die feeste van God is almal genadegawes.
1 Hulle is gebou op 'n fondament;
2 vanuit die waarheid is hulle beplan
ולכל קדש וימונים 3 en hulle is geheel en al heilige byeenkomste.
4 Israel word deur hulle verenig.
5 Die feeste is geproklameer as heilige byeenkomste.
6 Elkeen van hulle is afgesonder
והשמח והרגש 7 en dit gee vreugde en opgewondenheid.
8 Deur hulle word mense saamgebind.
9 En tog is hulle net sewe in getal.
10 Ons Heer proklameer hulle
11 en ek self maak hulle in jou teenwoordigheid bekend
ואגלי בון הסודים 12 en ek lê die insig in die geheime bloot.

ואשרי בזכרון הראש B 1 Waarlik, gelukkig is hulle wat die eerste maand herdenk

2 want in dié maand is redding bewerkstellig

3 vir Israel van dwangarbeid

: 4 en van die plek van slawerny.

5 En hulle het die pasga glorieryk gevier

6 met skape en beeste.

7 En hulle het uit Egipte uitgetrek teen dagbreek

8 maar hulle vyande het ten gronde gegaan.

9 En tydens die tweede maand, was Israel in die middel var die see.

10 Hulle het ongedeerd deurgetrek,

11 maar die perde van die Farao wat op hulle agterpote gestaan het,

12 het in die golwe weggesink.

וחילו וכל צבאו 1 En sy leër en al sy soldate 
2 het in die geweldige waters weggesink.

3 Maar Israel het ongedeerd uitgegaan

: 4 en hulle het God geprys.

5 En die derde maand, in dié maand is die wonderwerke geopenbaar

6 toe die stem van die God van die winde gehoor is

7-die spreke vanaf ses oorde

8 in vuur en duisternis en wolke en fakkels.

9 En die stem het uit die hoogte gekom

10 van die Een wat magtig is.

11 Hy het uitgeroep :'Ek is Jahwe

12 wat jou met my hand uit slawerny uitgelei het.'

ככן שביע החרשים 1 D 1 Soos volg is die sewende van die maande:

2 - sy genadegawes is nie vergeet nie.

3 En in dié maand is die verskyning van die vier belangrikste sake.

4 Waarlik in dié maand is die vier vasgestelde feeste.

5 Die eerste dag is 'n heilige byeenkoms

והעשירי כפורים אתפרש 6 en die tiende dag is afgesonder vir die Groot Versoendag,

7 want op dié dag is daar verlossing vir 'n mens

: 8 van sy oortredings by vorige geleenthede.

9 En op dié dag word gebede verhoor.

10 Op grond daarvan moet hulle vas staan in die verlossing

11 en moet hulle hulleself verootmoedig,

ויטיבו העובדים 12 en moet hulle die slawe reg behandel.

E 1 Soos volg is dit op die vyftiende dag:

2 Van dié dag af is dit die fees van insameling waarin

3 elke heerlikheid gesetel is.

4 En so word op dié dag vier glansryke gebeure uitgevoer.

5 Daarop moet hutte gemaak word

6 van die vrugte van sierlike bome met takke van

7 palmbome en takke van digte bome,

: 8 en van die rivierwilgers van Zabedim.

9 Dit simboliseer die vier strome wat uitgaan vanuit die עדנה Paradys. 
10 Dit simboliseer die vier seisoene van die jaar. 11 Dit simboliseer storaksgom en naeltjies en wierook

והלבניה סמים בבדים : 12 en galbanum, speserye in gelyke hoeveelhede.

היא כארבע אקרי הבריה היא כארבע פאתי עלמיה פיביה

היא כארבע טוריה דעל החשן היו עבידים

היא כרקיע מתפרש העיש וכוכבים מתכנש כריקיע עם ירח וֹשממש

היא שני עמודים :

סוד הסכות יתר

ממו נצא ונצבר

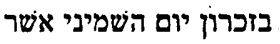

הוא חסול המועדים :
F 1 Dit simboliseer die vier kernelemente van die skepping.

2 Dit simboliseer die vier windrigtings van die wêreld.

3 Dit simboliseer die vier rye edelstene

4 wat op die borssak (van die hoëpriester) aangebring is.

5 Dit simboliseer die uitspansel wat uitgestrek is,

6 en die sterre wat versamel is

7 met die maan en die son.

8 Hierdie is die twee pilare.

9 Die fondasie van die hutte bly oor

10 van dié dag af verval dit en word dit opgevolg

11 deur die herdenking van die agtste dag wat

12 die feeste afsluit.

G שביע מועדיה

2-waarlik dit is die allerheiligste dag.

3 Die heiligheid van dié dag is soos die son van helderheid

מובוביו מתנגדים

5 Dit word tereg verkondig,

6 dit word vasgebind met 'n binding.

7 En soos volg moet op dié dag georden word

: 8 die gewigtige beginsels.

9 Op dié dag moet die koning van Israel

10 die mandjie sonder tekortkominge neem,

11 en hy moet opstaan en daarmee opgaan na Bet El,

12 na die heiligste van die aanbiddingsplekke.

H 1 En hy moet gaan na die ingang van die tent,

2 en dan moet die priester uitkom na hom

3 terwyl hy die borssak aan het.

4 Dan moet die koning voor die priester die belydenisse uitspreek.

5 En die mandjie, die priester moet dit uit sy hand neem

, 6 en dit voor die altaar neersit, 
7 soos wat Jahwe hom beveel het

8 deur die diens van die hoogste van die leraars.

9 Daarop moet die koning sy tiende bring.

10 Sy hart en sy binneste moet bly wees,

11 en hy moet staan en bid tot sy Heer.

12 En in die teenwoordigheid van sy Heer moet hy sy hande uitstrek.

I 1 En met vrede in sy hart moet hy sê :

2 'Ek het die heilige goed weggeneem uit die heiligdom

3 en ek het dit gegee vir Leviete, vir vreemdelinge, vir weeskinders.

: 4 Ek het opgetree volgens al U verordeninge,

5 en van U bevele het ek nie afgewyk nie:

6 in my rou het ek nie geëet nie

7 en in my onreinheid het ek nie gegee nie.

: $8 \mathrm{Kyk}$ tog in ontferming neer vanuit U woonplek.

9 Jahwe sal neerkyk op julle

10 vanaf sy heilige woning en Hy sal julle verlos

11 van julle haat en julle booshede,

12 en uit julle midde sal dit weggedryf word'.

I 1 Dit is al my woorde aan julle.

2 Julle moet vandag saam daaroor nadink.

3 Waarlik Ek is wat Ek is.

\section{VORM VAN DIE GEBED}

Dit is duidelik dat hierdie gebed in die Liturgie volgens ' $n$ bepaalde rympatroon opgestel is. Brown wys daarop dat rym reeds ' $n$ belangrike stylelement by die opstel van die eerste deel van die Liturgie was (1966:xi, xii). Die feesliturgieë wat in 'n later stadium deel geword het van die Defter, het ook die rympatroon opgeneem (Brown 1966:xiii). Elke strofe bevat 12 reëls. Die reëls is in drieë gegroepeer op grond van die rympatroon. Elke strofe vertoon die volgende patroon: Die eerste drie reëls eindig op dieselfde rymklank. Dit word opgevolg deur een reël wat eindig op דים. Die volgende drie reëls het dieselfde rymklank en word weer opgevolg deur een reël met 
Vir 'n derde keer herhaal die patroon. Dit wil sê, daar is in elk van die nege strofes twaalf reëls wat in groepe van drie saam gegroepeer is. Elke groepie word afgewissel met een reël wat eindig op דים. Die rymklanke is nie volgens ' $n$ vaste patroon ingerig nie. Die eerste reël (Aa) van die Liturgie is ' $n$ inleidingsformule en is dus nie deel van die rymskema nie. Die laaste drie reëls van die stuk vorm 'n samevatting en afsluiting van die stuk en is ook nie deel van die rymskema nie. Dit is moontlik dat die rympatroon doelbewus so ingerig is om te help met die memorisering van die Liturgie in die mondelinge oorleweringstadium.

Die rympatroon het ook implikasies vir die Liturg se gebruik van sy bronne. Die inhoud van die tekste wat die samesteller van die Liturgie gebruik, of dit nou uit die Pentateug of uit ander bronne afkomstig was, moes ingeforseer word by die rymskema. Om hierdie rede is dit nie moontlik om die Pentateug-tekste woordeliks in die Liturgie terug te vind nie.

Dit wil voorkom of die samesteller van die Liturgie 'n doelbewuste poging aangewend het om die aantal woorde per reël te beperk. Die lengte van die reëls wissel tussen twee tot vyf woorde per reël. Die oorwegende getal woorde per reël is drie. Verdere studie in dié verband is egter nodig.

\section{AANTEKENINGE BY DIE TEKS}

Die inhoud van die teks van die Liturgie wat vertaal is, word vergelyk met verwante tekste in die Masoretiese Pentateug. Telkens waar daar in die studiestuk na die Pentateug verwys word, is die bedoeling dat daar na die Masoretiese Pentateug verwys word. Dit is wel 'n leemte in dié studiestuk dat die Liturgie nie met die Samaritaanse Pentateug vergelyk word nie. Die doel van dié studiestuk is egter om twee verskillende tradisies met mekaar te vergelyk. Die verwantskappe word geklassifiseer in drie groepe, naamlik woordelikse ooreenkomste, parafraserende ooreenkomste en sinspelings.

\section{Aa מועדי אלהים}

Die uitdrukking kom nie woordeliks in die Pentateug voor nie. In die kontekste van die Pentateug waar die term na feeste verwys, word daar na spesifieke feeste verwys. Dit is die geval in Eksodus 13:10; 23:15 en 34:18 waar na die fees van ongesuurde brode verwys word. In Numeri 9:2 verwys die term na die pasga, in Deuteronomium 16:6 na die paasfees en in Deuteronomium 31:10 na die loofhuttefees. Dit is slegs in Levitikus 23:2 waar daar in die algemeen na die feeste verwys word. Die Liturgie kan sinspeel op Levitikus 23:2 wat ook deel is van die inleiding tot 'n feeskalender. Kraus (1966:34) onderskei by die Pentateug-tekste wat oor die feeste handel, twee groepe: die kalenders en die voorskrifte vir die rites. Die kalenders noem die name van die 
verskillende feeste wat voorkom (bv Lev 23:44). By die voorskrifte vir die rites word die offers genoem wat tydens elke fees nodig is (bv Lev 23:9-14). Kenmerkend van die kalenders is dat hulle מועדי יהוה genoem word. In die Liturgie vind ons die verwante benaming מועדי אלהים. Dit is dus geregverdig om die afleiding te maak dat die teks in die Liturgie handel oor die feeste wat in die kalenderjaar voorkom.

Wanneer die subjek van 'n sin die jukstaposisie beklee, word dit die casus pendens genoem. Die Liturgie maak gebruik van die casus pendens om die rymwoorde laaste in die $\sin$ te plaas en so die rympatroon te behou. Die verskynsel kom in die Liturgie onder andere voor in die volgende reëls: $\mathrm{Aa}, \mathrm{A} 10, \mathrm{~B} 8, \mathrm{~B} 11, \mathrm{C} 3, \mathrm{C} 9, \mathrm{D} 2$. In die volgende reëls word die persoonlike voornaamwoord gebruik om die subjek aan te dui (Kautzsch 1989:458): E9, 10, 11 en F1, 2, 3, 5, 8, 12.

\section{קדש וימונים Aan}

Grammatikaal kan hierdie vorm 'n superlatief wees. Kautzsch (1988:431) wys daarop dat 'n superlatief gevorm kan word deur 'n substantief in die status constructus met 'n woord van dieselfde stam of ' $n$ woord met dieselfde betekenis, daarnaas (bv Eks 10:22). Inhoudelik hou die Liturgie hier verband met Eksodus 12:16 waar na 'n heilige byeenkoms tydens die paasfees verwys word. Die bepaalde reël in die Liturgie verwys nie na die paasfees nie, maar die bedoeling van 'n heilige byeenkoms is dieselfde.

\section{אתקרו מקראי קדש D5}

Dit wil voorkom of die Liturgie hier dieselfde woorde as Levitikus 23:2 en 37 gebruik. Dieselfde werkwoordstam word in die Liturgie gebruik alhoewel dit in 'n ander stamformasie staan. Soortgelyke uitdrukkings kom ook voor in Eksodus 12:16 en Numeri 29:12. Die Liturgie gee die inhoud van Levitikus 23:2 parafraserend weer.

\section{A7 והשמח והרגש}

Die twee werkwoorde kom nêrens in die Pentateug in kombinasie voor nie. Dit is wel duidelik uit tekste soos Deuteronomium 16:15 en Levitikus 23:40 dat die feeste deur blydskap gekenmerk moes word. In Psalm 2:1 word die hapax legomenon רגו aangetref en dit kan vertaal word met 'onrustig wees'. In die verband waarin die woord in die Liturgie staan, sal dit eerder met 'n sinoniem van משח vertaal moet word.

\section{ומבית העבדים B4}

Die uitdrukking kom algemeen voor in die Pentateug. Alhoewel die Liturgie hier 'n woordelikse verwantskap met die Pentateug vertoon, is dit moeilik om vas te stel watter deel spesifiek aangehaal word, aangesien die uitdrukking so algemeen is. Dit is van groter belang om vas te stel wat die funksie is wat die uitdrukking in die Liturgie ver- 
vul. Na my mening staan die uitdrukking in die Liturgie in dieselfde konteks as wat dit die geval is in Deuteronomium 24:18, 22. Op grond van God se verlossingsdade kan die volk opgeroep word tot absolute gehoorsaamheid aan die voorskrifte vir die feeste. God se verlossingsdade word dan vervolgens genoem in die Liturgie. Die uitdrukking kom ook voor in Eksodus 13:3, 14; 20:2 en Deuteronomium 5:6; 6:12; 16:12.

\section{B5 הפסח באיקר}

God word soms ציקר פקר genoem (Montgomery 1968:215). Daar kan 'n verband wees tussen die woord in die Liturgie en die titel vir God. Dan sal die Liturgie lees: 'die paasfees van God'. Die voorsetsel $\geq$ gee egter 'n probleem en daarom word daar eerder gekies vir die vertalingsmoontlikheid wat Jastrow gee, naamlik 'heerlikheid of glorieryk'. Die instelling van die pasga word bespreek in Eksodus 12:1-28; Numeri 9:1-14 en Deuteronomium 16:1-8. Numeri 9:2 kan moontlik hulp verleen met die vertaling van dié uitdrukking in die Liturgie. Numeri 9:2 het die parallelle uitdrukking הפסח במועדו. Die Liturgie bevat 'n soortgelyke uitdrukking met die verskil dat dit מועדו מיקר in plaas vanduidelik is, kan dit moontlik wees om die vertalingsmoontlikheid wat Numeri 9:2 bied, in te lees by die Liturgie. Dit sou dus moontlik wees om die Liturgie na analogie van Numeri 9:2 in dié verband te vertaal met 'die pasga op die vasgestelde tyd'.

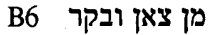

Deuteronomium 16:2 is die enigste teks wat in verband met die pasga praat van 'n viering met klein- én grootvee. Eksodus 12:4, 5 verwys slegs na 'n lam, skaap of 'n bok (dus kleinvee). Numeri 9 verwys slegs na die paaslam. Dit is moontlik dat die Liturgie die teks in Deuteronomium woordeliks gevolg het.

\section{B7 וצאו ממצרים בבקר}

Die Liturgie stel dat die volk uit Egipte getrek het met dagbreek. Die stelling verskil van Eksodus 12:31, 42 waar gestel word dat Israel in die nag uit Egipte vertrek het. Numeri 9:5 en Deuteronomium 16:1, 6 ondersteun die teks in Eksodus. Die volk het die pasga in die aand gevier en in die aand uit Egipte vertrek.

De Vaux (1988:182) wys daarop dat daar verskille ingetree het in die wyse waarop die begin van die nuwe dag bereken is. Aanvanklik het Israel 'n soortgelyke berekening as in Egipte gevolg, naamlik dat die dag begin met sonsopkoms. Later, onder Mesopotamiese invloed, is die dag bereken vanaf sonsondergang. Die verandering in berekening het ingetree tussen die tyd van die monargie en die tyd van Nehemia. De Vaux kies vir ' $n$ tyd aan die begin van die Ballingskap. Die tradisie waarop die Litur- 
gie in hierdie geval teruggaan, dateer uit 'n tyd voor die Ballingskap. Die Liturgie weerspieël dus 'n ouer tradisie as wat in die bogenoemde Pentateug-tekste aangetref word.

\section{B9-12 בתוך הים עברו בשלם וסוס פרעה דאתרים במצלות היו ירדים}

Die Liturgie bied 'n parafraserende weergawe van die gebeure soos wat dit beskryf word in Eksodus 14:23, 27 en 15:19. Die Liturgie vermeld niks oor die rol van Moses nie. Dit is opvallend dat die Liturgie so min maak van die rol van Moses, aangesien hy 'n prominente plek in die teologie van die Samaritane inneem (Montgomery 1968:225).

\section{וחילו וכל צבאו במים אדירים טבעו וישראל שלומים צאו C1-3}

Die Liturgie het die gebeure soos wat dit beskryf word in Eksodus 14:17, 28 en 15:4, 10, 19 parafraserend opgeneem. Eksodus 14:23 gee 'n meer volledige inventaris van die agtervolgers van Israel. Die Liturgie gee nie so 'n volledige beskrywing nie. Dieselfde uitdrukking wat in Eksodus 15:10 gebruik word om die waters van die see te beskryf, word woordeliks in die Liturgie opgeneem. Die Liturgie gebruik 'n uitsonderlike uitdrukking om Israel se deurtog te beskryf (שלומים). Die uitdrukking kom nie in die Pentateug voor nie.

\section{ולאלה היו מודים C4}

Die Liturgie sinspeel waarskynlik op die lied wat Israel gesing het nadat God die oorwinning oor die Egiptenare gebring het. Die lied is opgeteken in Eksodus 15:1-21.

\section{והשלישי בו אתגלא תמחות C5}

Die Liturgie verwys na die derde maand ná Israel se vertrek uit Egipte. Drie maande na die uittog het Israel hulle by Sinaiberg bevind (Eks 19:1-3).

\section{אלהי הרוחות C6}

Die eienaardige Godsnaam, 'God van die geeste', kom woordeliks voor in die Pentateug (Num 16:22; 27:16). Die Liturgie sinspeel moontlik op die wonderwerk by die Rietsee. Eksodus 14:21 en 15:8 vertel hoe God 'n sterk wind laat waai het om die water van die see te skei, sodat Israel op droë grond kon deurtrek. In die lig hiervan kan die benaming ook met 'God van die winde' weergegee word. 


\section{מדבר מששה הפאות C7}

Die Liturgie verwys hier na die ses plekke vanwaar die stem van God weerklink het. Die bedoeling kan wees dat dit uit die vuur, die duisternis, die wolke, die fakkels, uit die hoogte en vanaf God self geklink het. 'n Ander moontlikheid is dat die ses rigtings waarna verwys word, op die vier windrigtings, sowel as bo en onder, dui.

\section{באש וחשך וענן ולפידים C8}

Die teenwoordigheid van God word hier hiperbolies voorgestel deur vier elemente: vuur, donkerte, wolke en fakkels. In die Pentateug verskyn God by tye in die vorm van vuur (Eks 3:4), 'n wolk (Eks 13:21; 24:16; 34:5) en 'n fakkel (Gen 15:17). God praat ook uit die duisternis (Deut 5:23). Deuteronomium 4:11 kom die naaste aan die verwysing van die Liturgie. Deuteronomium 4 noem vuur, duisternis, wolke en wolkedonkerheid in plaas van fakkels. Al vier die elemente word in die Liturgie genoem om die heilige teenwoordigheid van God te beklemtoon.

\section{קעימה C10}

Montgomery wys daarop dat die Godsnaam ('Die Een wat Bestaan') gereeld voorkom in die Samaritaanse literatuur (Montgomery 1968:215). Filo (De nom. mut.) gebruik die term wanneer hy na God verwys.

\section{קרי אנכי יהוה דאפקתיך מידי העבדים C11-12}

Volgens die Liturgie stel God Homself bekend as die God wat Israel met 'n sterke hand uit slawerny uitgelei het. Die uitdrukking kom ook voor in Eksodus 6:1; 13:3, 14, 16 en Deuteronomium 7:8; 9:26. Daar is dit telkens Moses of die volk wat die woorde uitspreek. Slegs in Eksodus 6:1; 20:2 en Levitikus 26:13 is God aan die woord waar Hy Homself openbaar as die God wat Israel uit die slawehuis uitlei. (Eks 6:1 bevat 'n soortgelyke uitdrukking wat onvolledig is.) By Eksodus 20:2 en Levitikus 26:13 ontbreek die uitdrukking 'met 'n (sterke) hand', soos dit in die Liturgie voorkom. Die Liturgie kan 'n parafrasering van die twee teksverse wees. Eksodus 15:6 besing die sterke hand van God. Die Liturgie kon ook dié verwysing in gedagte gehad het.

\section{שביע החדשים}

Drie feeste in die sewende maand word beskryf in Levitikus 23:23-36, 39-43; Numeri 29:1-40 en Deuteronomium 16:9-17. Die eerste dag van die sewende maand is die Nuwejaarsfees. Op dié dag is daar 'n heilige byeenkoms van die volk.

Die tiende dag van die maand is die Groot Versoendag. Op dié dag is daar 'n heilige byeenkoms waarop daar versoening gedoen word vir die sonde van die volk. Vanaf die vyftiende dag van die maand word die Huttefees vir sewe dae lank gevier. Op die eerste en agtste dag is daar heilige byeenkomste vir die volk. 


\section{בו ארבע מועדים D4}

Die Liturgie gee 'n aanduiding dat daar vier feeste in die sewende maand is. Uit die aantekeninge by $\mathrm{D} 1$ is dit duidelik dat die Pentateug slegs drie feeste in die sewende maand identifiseer. Dit is moontlik dat die Samaritane die Sabbatdag as die vierde feesdag van die sewende maand gereken het. Levitikus 23:3 noem duidelik dat die Sabbatdag ook ' $n$ feesdag is soos al die ander feesdae wat voorgeskryf is. Die stelling word ook later bevestig as die Liturgie net die genoemde drie feesdae van die sewende maand noem in D4-E1. Dit veronderstel dat die Sabbatdag wat regdeur die jaar voorkom, in elke maand as feesdag gereken word. 'n Ander moontlikheid is dat die Liturgie die agtste dag van die huttefees as die vierde fees beskou (vergelyk F11). Die feesdag word dan in besonderhede bespreek in G1-I12. (Vergelyk ook die aantekeninge by $\mathrm{G} 1$ in dié verband.)

\section{רישה זימון קרש}

Levitikus 23:24 en Numeri 29:1 noem die fees op die eerste dag van die sewende maand ook 'n heilige dag. Hier is egter geen woordelikse verwantskap tussen die Liturgie en die Pentateug nie.

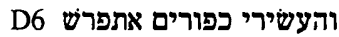

Die Liturgie verskil van Levitikus 23:27 en Numeri 29:7 in dié opsig dat die telwoord 'tien' anders gevokaliseer word en dat die vol skryfwyse in die Liturgie gebruik word om na die fees te verwys. Die Liturgie vertoon 'n parafrasering van die Pentatēuginhoud.

\section{ויתנו לנפשותיון ענותה D11}

Dit is moontlik dat die Liturgie dieselfde werkwoordstam gebruik het as wat in Levitikus 23:27 voorkom (עניתם). Dié uitdrukking in die Liturgie kan 'n uitdrukking wees wat eiesoortig is aan Noord-Israel. Die uitdrukking kan selfs 'n wisselvorm wees vir die uitdrukking soos dit in Levitikus 23:27 voorkom.

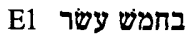

Dié telwoord in die Liturgie moet hier met 'vyftien' vertaal word. Kautzsch (1988:290) wys daarop dat

Dié uitdrukking in die Liturgie verskil van Levitikus 23:34 en Numeri 29:12, waar dit ook voorkom. Die naamwoord oi ontbreek in die Liturgie. Die telwoord kan daarom in die manlike vorm staan. 


\section{חג האסף}

Die fees van die oes het in die eerste maand, Nisan (vroeër bekend as Abib), plaasgevind. In die tweede maand, ljjar (vroeër bekend as $\mathrm{Sif}$ ), is die garsoes ingesamel. Die tyd van die feeste is bepaal deur die oestye. Die olyfoes het in die sesde maand, Elul, plaasgevind. Daar was ook 'n tyd van insameling in die sesde maand. Volgens Deuteronomium 16:13 was daar oes- en insamelingsfeeste in die sewende maand. Die huttefees en die fees van insameling val volgens Levitikus 23:39 saam. Vergelyk die aantekeninge by $\mathrm{Gl}$ in dié verband.

\section{איקר E3}

Daar bestaan vier moontlike verklarings vir die woord.

* Dit het die betekenis soos wat Jastrow dit aandui, naamlik 'heerlikheid, glorieryk'.

* Dit is 'n wisselvorm vir die naam van die tweede maand, Ijjar.

* Dit hou verband met die Godsnaam עיקר, אקר (Wortel, Beginsel).

* Dit kan ook verband hou met die naamwoord wat verwys na 'wortel'. Dan funksioneer die naamwoord nie as 'n eienaam nie.

Die moontlikheid wat Jastrow bied, lyk in dié konteks die waarskynlikste. Die vorm van dié woord in die Liturgie kom presies so voor in Jastrow.

\section{יעבד בו סכות E5}

Die Liturgie brei vervolgens uit oor die vraag hoe die hutte gebou moet word. In die Liturgie word die naamwoord o telkens saam met die werkwoord in die enkelvoud gebruik. Die sinsnede wat in die Liturgie voorkom, kom nie in die Pentateug voor nie. 'n Gedeelte wat die naaste daaraan kom, is Levitikus 23:42. Nehemia 8:16 is nader aan die teks van die Liturgie, maar aangesien die Samaritane net die Pentateug gebruik, is dit te betwyfel of die sinsnede uit Nehemia sou kom. Dit is tog moontlik dat die Liturgie en Nehemia 8:16'n gemeenskaplike bron gehad het.

\section{פרי צץ הדר כפות תמרים וצנפי עץ עבות וערבי נחל זבדים E-8}

Die Liturgie stem hier woordeliks ooreen met die Pentateug-teks. Afgesien van die vol skryfwyse in die Liturgie, is daar geen verskil in die teks nie. 
Goldberg wys daarop dat die Rabbyne Levitikus 23:40 geïnterpreteer het as sou dit verwys na die takke wat ' $n$ Israeliet in die hand moet hou gedurende die feesverrigtinge van die huttefees. Die Karaïete ('n Joodse sekte) het weggedoen met die gebruik. Die tradisionele Joodse siening is dat slegs Nehemia 8:16-17 voorskryf hoe die hutte vir die fees gebou moet word. Die Rabbyne het verskil oor die aangeleentheid. Sommige van hulle meen dat die hutte van dieselfde soort moes wees as die takke wat in die hand gehou word. Ander meen weer dat die hutte van ander materiaal gebou moes word as die takke wat in die hand gehou word (Goldberg 1957:120).

Levitikus 23 en die Liturgie verwys na vier boomsoorte. Nehemia 8 verwys na vyf boomsoorte.

\section{בארבע נהרים צאו מן עדנה E9}

Die Liturgie verwys na Genesis 2:10-14 waar daar melding van twee riviere met vier lope gemaak word, naamlik die Pison, Gihon, Hiddekel en Frat.

\section{נטף ושחלת ולבונה והלבניה סמים בבדים E11-12}

Die teks-edisie van Cowley kan met die woord הלבניה 'n drukfout in hê. Na alle waarskynlikheid moet dit lees חלבניה. Volgens so 'n lesing sal die Liturgie al vier die elemente wat in Eksodus 30:34 genoem word, weergee. Dit wil voorkom of die Liturgie die inhoud van die Pentateug in hierdie verband parafraserend weergee. Die vier feeste van die sewende maand word vergelyk met vier waardevolle speserye.

\section{כארבע אקרי הבריה F1}

Die Liturgie kan verwys na die vier tradisionele elemente waaruit die aarde bestaan, naamlik vuur, water, grond en lug. Daar bestaan geen parallel hiervoor in die Pentateug nie. Tog verwys Heidenheim daarna dat die Samaritane op grond van letterspel die letter 7 (die vierde letter in die Hebreeuse alfabet) assosieer met die elemente van die aarde.

\section{היא כארבע טוריה דעל החשן היו עבידים F-8}

Die Liturgie gee die inhoud van Eksodus 39:8, 10 parafraserend weer. Dieselfde woorde word gebruik, maar die detail van die Pentateug word uitgelaat. Die borssak word ook in Eksodus 28 en Levitikus 8 bespreek. 


\section{F6 כוכבים מתכנש}

In die Pentateug word die uitdrukking 'sterre van die hemel' telkens gebruik in verband met die nageslagbelofte (Gen 22:17; 26:4; Eks 32:13; Deut 1:10). Die Liturgie praat hier slegs van 'sterre'. Moontlik sinspeel die Liturgie op hoe groot die volk is of op die grootheid van die feeste van die sewende maand. Die 'sterre wat versamel is', kan verwys na die magdom sterre wat sigbaar is in die melkweg.

\section{F7 ירח וששמש}

Die Liturgie beklemtoon die grootheid van die feeste van die sewende maand deur dit te vergelyk met die grootheid van die skepping van die son, maan en sterre (Gen 1:14$18)$.

\section{F8 yמורים}

God se teenwoordigheid by die volk is sigbaar in die wolk- en vuurkolom. Dit is duidelik uit tekste soos Eksodus 13:21; 14:24 en Numeri 13:13. Dieselfde woord wat in die Pentateug gebruik word vir 'kolom' word in die dualisvorm in die Liturgie gebruik. Dit is moontlik dat die Liturgie verwys na die wolk- en vuurkolom wat in die Pentateug ter sprake is. Daar is voortdurend 'n vergelyking tussen vier sake. Heel onverwags word die vergelyking verminder tot twee sake. Die vergelykingspunt moet nie in die getal gesoek word nie, maar in die rol van die wolk- en vuurkolom. In die Pentateug dien die kolom as simbool van God se teenwoordigheid. Die Liturgie wys daarop dat die feeste tekens is dat God teenwoordig is by die volk.

\section{בזכרון יום השמיני אשר F11}

Die rangtelwoord word gevorm deur'. aan die telwoord te voeg (Kautzsch 1988:292). Die Liturgie kan hier vertaal word met 'In herinnering van die agtste dag.' Israel het die huttefees agt dae lank gevier (Lev 23:36, 39; Num 29:35; Neh 8:19; 2 Kron 7:9$10)$. Die agtste dag was ' $n$ gewone Sabbatdag waarop geen werk gedoen is nie.

Die Liturgie verwys ook na die agtste dag van die huttefees as ' $n$ feesdag. Die opskrif by die teks van die Liturgie wat vertaal word, kan so geinterpreteer word as sou dit verwys na 'n gebed wat op die agtste dag van die huttefees gebid is.

Die loofhuttefees het 'n bepaalde ontwikkelingsgeskiedenis gehad. Ongeag die vraag of die fees sy oorsprong in Kanaänitiese landboufeeste het of nie, word in die Pentateug verskillende stadia van die huttefees weerspieël. In Eksodus 34:22 word die fees van insameling vermald sonder vermelding van die hutte wat gebou moet word. 
Die fees is aan die einde van die jaar. Deuteronomium 16:13-15 noem ook die fees van insameling. Dit is reeds ' $n$ tweede fase van ontwikkeling. Die loofhuttefees word in Levitikus 23 uiteengesit. Volgens die priesterkodeks is die eerste en agtste dag 'n feesdag. Die verwysing na die hutte wat gebou moet word (Lev 23:40), is 'n latere toevoeging tot die tradisie. Die fees het gepaard gegaan met die verbondsvernuwing en wetsvoorlesing. Rylaarsdam verwys daarna dat die sewe dae lange huttefees opgevolg is deur twee ekstra dae van feesviering. Die agtste dag is as feesdag gevier. Dit was nie heeltemal deel van die huttefees nie (Lev 23:36). Die negende dag het bekend gestaan as die Simchat Torah (vreugde oor die wet; Rylaarsdam 1989:456). Dit is dus moeilik om te bepaal uit watter van die stadia wat weerspieël word in die Pentateug, die Liturgie sy verwysings put.

\section{G1-2 שביע מועדיה וקדש קדשיה}

In die Liturgie word die feeste van Israel besing. Reël 4 van die Liturgie noem dat die getal van die feeste sewe is. Die volgende feeste kan geïdentifiseer word in die Liturgie:

* B1 noem die eerste fees. Die pasga is ' $n$ fees in die eerste maand van die jaar. Tydens die fees word die verlossing uit Egipte herdenk.

* B9 noem die tweede fees. Die deurtog deur die see word as 'n volgende herdenkingsgeleentheid gevier.

* C5 noem die derde fees. In die derde maand word die openbaring by Sinai as herdenkingsgeleentheid gevier.

* D5 noem die vierde fees. Op die eerste dag van die sewende maand is daar 'n heilige byeenkoms van die volk. Die fees het nie 'n spesifieke naam nie.

* D6 noem die vyfde fees. Op die tiende dag van die sewende maand is dit die Groot Versoendag.

* E1 noem die sesde fees. Vanaf die vyftiende dag van die sewende maand is dit die fees van insameling. Tydens die fees moet die volk hutte bou om in te woon. Die fees duur agt dae lank.

* G1 noem die sewende fees. Dit is die allerheiligste fees van al die feeste. Tydens die fees moet die koning van Israel ' $n$ tiende na die priester by Bet-El bring. Die 
prosedure waarvolgens dit moet plaasvind, word breedvoerig beskryf. Dit is moeilik om vas te stel of die fees op die agtste dag van die huttefees moet plaasvind en of dit die fees in die agtste maand is waarvan ons lees in 1 Kon 12:33 (vergelyk Gevolgtrekking).

Die Israeliete het ' $n$ lente- of herfskalender gevolg. Die feit dat die Liturgie die pasga as die eerste fees van die jaar aandui, gee 'n aanduiding dat die Liturgie 'n lentekalender volg. Daar is wel 'n nuwejaarsfees in die herfs. Die heilige byeenkoms op die eerste dag van die sewende maand het later bekend geword as die nuwejaarsfees. As die nuwejaarsfees in die herfs as die eerste fees van die jaar aangedui sou word, sou die Liturgie 'n herfskalender gevolg het. De Vries (1989:484) dui aan dat 'n herfskalender oorwegend in Juda nagevolg is en dat Jerobeam in die Noorde die lentekalender weer ingestel het.

\section{בקשור מתקשר G6}

Die Liturgie sinspeel moontlik op die gebedsbande wat om die hand en voorkop gebind moet word (Deut 11:18). Dieselfde woord word in die Liturgie en Pentateug gebruik vir 'ombind' (Deut 6:8).

\section{איקרים כבדים אי אי אי}

Die term עיקר kan verband hou met die Godsnaam (vgl aantekeninge by E3). Die woord כבד word in die Pentateug gebruik om te verwys na die heerlikheid van God (Eks 24:17; 33:22; 40:34). Die twee Hebreeuse terme kom egter nooit in kombinasie in die Pentateug voor nie. Dit is moontlik dat die twee terme in die Liturgie na God verwys. 'n Ander moontlikheid is dat איקר in hierdie konteks eerder vertaal kan word met 'wortels, beginsels'.

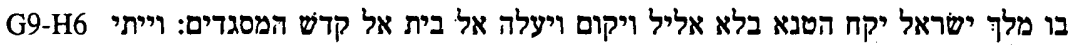

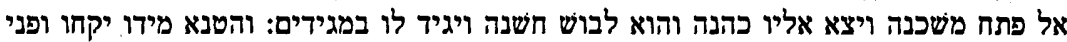

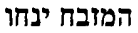

Die Liturgie gee die teks uit Deuteronomium 26:2-4 parafraserend weer. Dieselfde woorde word gebruik, maar die besonderhede verskil. Die gevolg is dat hier nie sprake kan wees van woordelikse ooreenkoms nie. Die eerste verskil tussen die Liturgie en Deuteronomium 26 is die subjek. Volgens die Liturgie is dit die koning van Israel wat die handeling moet uitvoer. Volgens Deuteronomium 26:1-2 is dit die gewone Israeliet wat dit moet doen. Die praktyk dat die koning van Israel die offer moes bring, is ' $n$ voortsetting van 'n praktyk wat reeds by Dawid en Salomo te bespeur is. Na my mening is dit meer waarskynlik dat die Samaritane die gebruik oorgeneem 
het uit Noord-Israel en wel van Jerobeam (1 Kon 12:33 e v). Die praktyk om die mandjie met eerstelinge van die vrugte-oes na die priester te bring, het in die fees van die weke voorgekom. Die mandjie was 'n teken van die seëninge wat die volk in die beloofde land ervaar het. Deuteronomium 26 weerspieël die ontwikkeling waar die fees van insameling die loofhuttefees geword het (Vergelyk Deut 16:13-15). Deuteronomium 26:2-4 vermeld egter nie die hutte wat tydens die huttefees gebou moet word nie (Rylaarsdam 1989:456).

'n Tweede verskil is die plek waarheen die mandjie gebring moes word. Die Liturgie noem die plek bēt-'él (Die huis van God). Dit is moontlik dat dit as eienaam gelees moet word en dan dui op die heiligdom by Bet-El. Die Samaritane se heiligdom was egter by Sigem geleë. Aangesien die tradisie oor die tiendes tradisioneel met BetEl verbind word (Gen 28:19, 23), is dit nie vreemd dat die Liturgie hier verwys na die tiendes wat na Bet-El gebring moet word nie. Bet-El was ook die staatsheiligdom van die Noordryk (1 Kon 12:29). Die Pentateug is nie eksplisiet oor waarheen die mandjie gebring moet word nie (Deut 26:2). Die Liturgie kwalifiseer Bet-El as die 'heiligste van aanbiddingsplekke' (G12). Aangesien Sigem ook 'n belangrike aanbiddingsplek vir die twaalf stamme voor die totstandkoming van Jerusalem as hoofstad was (Reed 1989:314), wil dit voorkom of die Liturgie 'n tradisie weerspieël wat uit 'n tydperk voor die sentralisasie van die kultus dateer. Daar het in die Noorde gelyktydig verskillende heiligdomme onafhanklik van mekaar bestaan. Silo (Jos 22:9), Sigem en Bet-El (1 Kon 12:26-33) was van die belangrikste aanbiddingsplekke in die Noorde (Montgomery 1968:16,234).

Die Liturgie gee nie soos Deuteronomium 26:3, 5-9 die inhoud van die belydenis wat die handelende persoon teenoor die priester moet uitspreek nie. Die Liturgie noem wel dat ' $n$ belydenis gedoen moet word. Die woord wat in Deuteronomium 26:3 gebruik word (הגדתי) om na die uitspreek van die belydenis te verwys, is dieselfde woordstam (נגד) wat die Liturgie opneem (ניגיד) om na die belydenis voor die priester te verwys. Die Liturgie kan deur dieselfde woordstam (נוגד) as Deuteronomium 26:3 te gebruik, die inhoud van die belydenis wat in die Liturgie ontbreek, in gedagte roep. Die mandjie word dan voor die altaar neergesit.

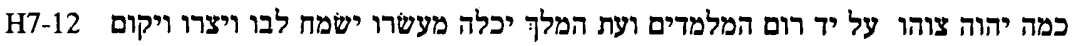

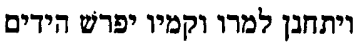

Die uitdrukking כמה יהוה צוהו למרוה in Levitikus verteenwoordig 'n geykte vorm wat die funksie het om eenhede saam te groepeer. Hier in die Liturgie het die uitdrukking nie dieselfde funksie as in Levitikus nie. 
In Deuteronomium 26:5-9 word die belydenis verwoord wat die Israeliet voor die priester moes doen. In die belydenis word gestel dat Israel se voorvaders rondtrekkende Arameërs was wat in Egipte gewoon het. Met verloop van tyd het hulle 'n magtige nasie geword. Die Egiptenare het die vreemde volk in hulle midde verdruk. God het Israel uit Egipte uitgelei en hulle gebring na die beloofde land. Die land waarin hulle nou woon, is 'n vrugbare land. Uit dank vir die verlosssing en die seëninge op die vrugbare land, bring Israel die eerstelinge van die oes na God.

Die Liturgie verwys na 'deur die diens van die hoogste van die geleerdes' wat God se bevele aan die familiehoofde meegedeel het. Die 'hoogste van die geleerdes' kan verwys na Moses. Binne die Samaritaanse teologie speel Moses 'n belangrike rol (Montgomery 1968:225). Moses het die verordeninge wat God vir sy volk gegee het, aan die familiehoofde bekend gemaak.

Deuteronomium 26:11 verwys na die vreugde (שמחת teenoor משמח (ישח) wat moet volg op die oes. Die gedagte word opgeneem in die Liturgie waar die vreugde en opgewondenheid in die hart van die koning vermeld word.

Die Liturgie vermeld 'soos wat Jahwe hom beveel het' (H7). Die persoon aan wie die bevele gerig is, kan die priester wees voor wie die koning die kultiese handelinge moet voltrek. Indien dié interpretasie waar sou wees, is dit geregverdig om te aanvaar dat die Liturgie bedoel is as handleiding vir die priesters.

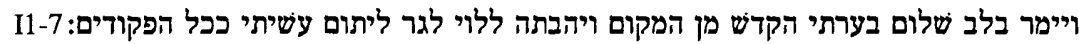

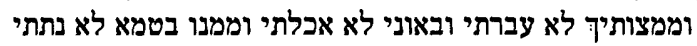

Die Liturgie gee die Pentateugteks (Deut 26:13) parafraserend weer. Daar bestaan wel verskille tussen die Liturgie en die verwante teks uit Deuteronomium 26. Die inleidingsformule tot die gebed verskil. Die Liturgie bevat die uitbreiding 'met 'n tevrede hart'. Die woorde מן הבית in Deuteronomium 26:13 wat in die Liturgie weergegee word as מון המקום verteenwoordig 'n verdere verskil. In Genesis 28:11, 17 word BetEl המקום kan die Lenoem. Met die woord (Gen 28:22). Bet-El was die koninklike heiligdom in die Noorde en het dieselfde status gehad as wat Jerusalem in die Suidryk gehad het (vgl 1 Kon 12:29, 32 ,33; 13:1).

Die werkwoorde wat op die oordra van die goedere dui, verskil. Die indirekte objekte van die handeling is dieselfde. In die Liturgie ontbreek לאלמנה. Die Liturgie gee die inhoud van die Pentateug waar dit handel oor die gehoorsaamheid aan God se bevele, parafraserend weer. Die Liturgie het 'n vreemde woordorde in die sinsnede וממצותיך לא עברתי, klaarblyklik ter wille van die eindrym met I6 en 7. Die Pentateug het die normale woordorde met die werkwoord eerste. In die Liturgie ontbreek dié deel waar die Pentateug stel dat die familiehoof nie die verordeninge van God mag vergeet nie. Die Liturgie het weer vreemde woordorde in die sinsnede 
אכלתי. Deuteronomium 26:14 het die normale Hebreeus. Die Pentateug het 'n uitbreiding by en ook ' $n$ herhaling van die frase 'soos u my beveel het'.

Die teks wil aandui dat die tiende nie geëet is onder omstandighede waartydens die persone onrein kon wees nie, byvoorbeeld tydens rou. Die tiendes is aangewend vir die versorging van die groepe in die gemeenskap wat buite ' $n$ familieverband gestaan het en dus niemand gehad het om vir hulle te sorg nie. Die koning was die voorganger vir die volk in die bring van die tiendes na die heiligdom. Die tiendes wat as offer na die altaar van God gebring is, is weer weggeneem uit die heiligdom en versprei onder die behoeftiges, naamlik die Leviete, wese, vreemdelinge en weduwees.

השקף ממעונף בחסדים: ישקף יהוה עליכון ממעון קדשו ויפרי יתכון מן סנאיכון18-11 ודבביכון

Die Liturgie gee die Pentateugteks (Deut 26:15) parafraserend weer. Die Pentateug spesifiseer wáár die heilige woning van God is, naamlik in die hemel. Die gebed in die Liturgie het ' $n$ ander bewoording as die Pentateug. Die Pentateug neig meer tot ' $n$ verbondsvernuwingtradisie. In die Liturgie word gebid om vergifnis van oortredings. Die versekering word ook gegee dat God die oortredinge sal vergewe. Brown wys daarop dat die Samaritaanse Liturgie eerder daartoe neig om te bid vir sondevergewing as om te bid vir nasionale eenheid, soos wat die geval by die Jode was (1966:xxvi). Die woord wat in die Liturgie gebruik word, is ויפדי. In Numeri 18:15 word die woord תפדה gebruik wat verwys na die handeling om die eersgeborene los te koop. In Deuteronomium 7:8 word die vorm ויפרך gebruik om te verwys na die verlossing uit die mag van die farao. In die konteks van die Liturgie is die betekenis van ויפרי ויפ eerder 'verlos' as 'loskoop'.

ישקף יהוה עליכון ממעון קרשו ויפדי יתכון מן סנאיכון ודבביכון וקמיכון יהיו מנדנדים I9-12 Hierdie woorde is moontlik 'n seënspreuk wat die koning oor die volk moes uitspreek. As in gedagte gehou word dat die konings van die Noordryk die funksie van priester waargeneem het ( $\mathrm{vgl} 1 \mathrm{Kon} 13: 1$ ), is dit waarskynlik dat die koning 'n seën oor die volk sou uitspreek nadat die offers gebring is.

\section{אהיה אשר אהיה J3}

Hierdie is 'n geykte uitdrukking wat net so in die Pentateug (Eks 3:14) voorkom. Die uitdrukking het in die Liturgie die funksie van. 'n afsluitingsformule. Montgomery wys daarop dat die woorde gereeld in die Liturgie voorkom (1968:214). 


\section{GEVOLGTREKKING}

Verwantskappe tussen die Liturgie en die Pentateug wissel vanaf woordelikse ooreenkomste tot sinspelings en parafraserings. Die verwantskappe kan verklaar word na aanleiding van drie hipoteses:

* Daar was gemeenskaplike bronne of tradisies vir die Masoretiese Pentateug en Samaritaanse Liturgie.

* Daar bestaan 'n literêre verbintenis tussen die Liturgie en die Pentateug. Dit wil sê dat die Liturgie-opstellers die Pentateug geraadpleeg het vir hulle gegewens.

* Ouer tradisies as wat in die Pentateug ter sprake is, kon deur die Liturgie gebruik word.

Die antwoord lê nie in 'n keuse vir slegs een van die hipoteses nie. Die oplossing is eerder te vinde in 'n kombinasiekeuse. Dit impliseer dat die Liturgie ' $n$ lang ontstaansgeskiedenis het waartydens ouer tradisies sowel as gemeenskaplike bronne én die Pentateug self gebruik is. Die opstellers van die Liturgie het gebruik gemaak van Pentateugmateriaal tot hulle beskikking. Die manier van omgang met die materiaal skep probleme. Die materiaal uit die Pentateug is ingepas by 'n rympatroon wat die opsteller gebruik het in die Liturgie. Op grond van die vaste rympatroon wat by die Liturgie voorkom, is dit verstaanbaar dat die materiaal wat uit die Pentateug oorgeneem is, meestal nie woordeliks sal ooreenstem nie. Daarom is dit nie noodwendig so dat die Liturgie ' $n$ ander bron of tradisie as die Pentateug gebruik het nie.

In die opmerkings by G1-2 word die aanname gemaak dat die Samaritaanse feeste wat in die Liturgie genoem word, verskil van die tradisionele Joodse feeste. Die term 'verskil' is nie geskik om te beskryf wat die verband tussen die Samaritaanse en Joodse feeste is nie. Hans-Joachim Kraus $(1966: 45,55,61)$ gaan van die standpunt uit dat daar drie belangrike Joodse feeste bestaan, naamlik die pasga, die lentefees en herfsfees. 'n Aanduiding van die driedeling vind ons reeds in Eksodus 23:14, 17. Hier word eksplisiet gestel dat daar van drie feeste sprake is waartydens Israel voor God moet verskyn. Oor die eeue is daar ander feeste by die bestaande Joodse feeste gevoeg (byvoorbeeld Purim en Hanukkah). Die feeste wat in die Liturgie genoem word (vgl opmerkings by G1-2 vir 'n volledige lys), hou verband met die Joodse feeste. Die pasga wat in die Liturgie genoem word, stem ooreen met die Joodse pasga. Wat ook al die oorsprong van die pasga was, die Jode en Samaritane het dit tot dieselfde heilsdaad teruggevoer, naamlik die verlossing uit Egipte. Die pasga is selfs vandag nog by die Samaritane die belangrikste fees (Kraus 1966:54). 
Die tweede Joodse fees van die jaar, was die fees van ongesuurde brode. Dit was oorspronklik ' $n$ landboufees. Later is dit met religieuse inhoud gevul. Deuteronomium 16:1-8 verbind die pasga en fees van ongesuurde brode tot een fees. Volgens Levitikus 23:4-8 is die pasga op 14 Nisan en die fees van ongesuurde brode vanaf 15 Nisan vir sewe dae gevier. Levitikus 23 begrond die feeste nie op historiese gebeurtenisse nie. Eksodus 23:15 verbind die fees van ongesuurde brode met die uittogtradisie.

In 2 Kronieke 30:2, 13 word vertel hoe die fees van die ongesuurde brode in die tweede maand gevier is. Die uitnodiging na die fees is deur koning Hiskia van Juda aan alle Israeliete gestuur, ook aan die Noordryk. Dit is duidelik dat die godsdiens van die Samaritane verbintenisse met die godsdiens van die Noordryk het. Dit is moontlik dat die fees waarna die Liturgie verwys, wat in die tweede maand plaasgevind het, die fees van die ongesuurde brode kon wees. Dit is duidelik op grond van Deuteronomium 16:1-8 dat die Jode met die pasga na beide die paasfees en die fees van die ongesuurde brode verwys het. Koning Jerobeam van die Noordryk kon die pasga (verwysende na die fees van ongesuurde brode) so ingerig het dat dit tydens die tweede maand gevier sou word. Hy het geweet dat hy nie al die Israeliete van die Noordryk kon weerhou om na die pasga in Jerusalem tydens die eerste maand te gaan nie. Daarom het hy ' $n$ fees ingestel in die tweede maand as teenvoeter teen die fees in Jerusalem (Kraus 1966:55). Sodoende kon hy die religieuse onafhanklikheid van die Noordryk konsolideer. Die Jode verwys dus na albei feeste, die paasfees en die fees van ongesuurde brode, as hulle praat van die pasga. Die Samaritane skei die twee feeste en vier hulle in die eerste en tweede maand onderskeidelik. Die Samaritane koppel die fees van die ongesuurde brode aan die uittogtradisie, soos dit ook die geval in Deuteronomium 16 is.

Die derde fees waarna die Liturgie verwys, is die naamlose fees wat gevier is by die berg Sinai. Die tweede groot fees van die Jode (die pasga en fees van ongesuurde brode is een fees), is die fees van die weke (Kraus 1966:55). Vroeër het die fees bekend gestaan as die oesfees (Eks 23:16). Met verloop van tyd is die fees vir 'n week lank gevier. Die fees het aangebreek vyftig dae na die fees van ongesuurde brode (Lev 23:16), of sewe weke na die koringoes (Deut 6:9). Die fees van die weke het geen verbintenis met enige historiese gebeurtenis in Israel nie. Dit is by uitstek ' $n$ landboufees. As gevolg van die oorname van die Assiries-Babiloniese kalender deur Juda, het die fees van die weke in die derde maand geval. Eksodus 19:1 verbind die Sinaiperikoop met die fees van die weke wat in die derde maand gevier is. Die wetsopenbaring by Sinai het 'n herdenkingsgeleentheid geword. Kraus (1966:591) stel dat die verbinding van die twee gebeurtenisse gebaseer is op 'n ouer tradisie. Dit is moeilik om die tradisie te dateer. Die tradisie wat in 2 Kronieke 15:10-14 weerspieël word, stel dat die fees van die weke gebaseer is op die verbondsvernuwing. Dit is 'n latere 
interpretasie van die fees. Tydens die fees is die verbondsvernuwing herdenk. Dié tradisie dateer uit die vierde of derde eeu v C. Die Liturgie weerspieël dus die tradisie van Eksodus 19 waar die fees van die weke verbind is met die aanbidding op Sinai. Dit is ' $n$ tradisie wat dateer uit 'n ouer stadium as die derde eeu $v \mathbf{C}$.

Die Liturgie noem vervolgens drie feeste wat gevier word tydens die sewende maand. Aanvanklik het al die feeste in die sewende maand bekend gestaan as die herfsfeeste (Kraus 1966:66). Die oorkoepelende term is gebruik om te verwys na die fees van insameling (חג האסף). Dit was 'n fees waartydens dank gebring is vir die oeste. Die oeste het ook die afsluiting van die landboujaar beteken. Later is die nuwejaarsfees ook in die siklus gevier. In die kalenders van Deuteronomium 16 en Levitikus 23 word die fees die חג הסכות genoem. Die huttefees is van Kanaänitiese oorsprong, maar Israel het dit met nuwe religieuse inhoud gevul. Tydens die oesfees het die arbeiders wat die landerye afoes, in hutte langs die velde gewoon. Die ouer tradisie het dit dus dat die hutte (סכות) deel was van die fees van insameling. Eers vanaf Levitikus 23:40 word die hutte verbind aan 'n historiese gebeurtenis in Israel se geskiedenis. Eers volgens ' $n$ latere tradisie het die huttefees 'n aparte fees geword (Kraus 1966:64). Volgens Levitikus 23:23 word die hele sewende maand toegeskryf aan die herfsfees. Tydens die sewende maand is die volgende feeste gevier: Op die eerste dag was daar ' $n$ heilige byeenkoms, op die tiende dag was die Groot Versoendag en vanaf die vyftiende dag is die huttefees vir agt dae lank gevier. Al die feeste het saam bekend gestaan as die fees van insameling (Kraus 1966:66 noem dit die herfsfeeste). Die fees op die eerste dag het geen spesifieke naam nie. Moontlik het die fees verband gehou met die reiniging van die heiligdom ter wille van voorbereiding van die huttefees. Die Ou Testament gee min inligting oor die Nuwejaarsfees. Die Groot Versoendag is ' $n$ baie ou fees wat moontlik so ver teruggaan as die woestynperiode van Israel (Kraus 1966:69). Die heilige byeenkoms en die Versoendag kon moontlik as voorbereiding van die huttefees wat op die vyftiende dag begin en vir agt dae duur, dien. Die Liturgie verwys na die fees van insameling (חג האסף) wat op die vyftiende dag begin. Deel van die fees het daaruit bestaan dat hutte (ס) gebou' is. Die Liturgie gebruik dus 'n ouer tradisie waar die huttefees nog as deel van die fees van insameling gereken is.

Die sewende fees waarna die Liturgie verwys, is die feesgebeurtenis wat vanaf G1 beskryf word. Die fees word as die heiligste gebeurtenis voorgestel. Die fees wat in die Liturgie beskryf word, lewer 'n paar probleme op. Die presiese tyd wanneer dit plaasvind, is onbekend. Die duur en die presiese naam daarvan word nie verstrek nie. Dit is duidelik dat die meeste klem op die sewende fees geplaas word. As in gedagte gehou word wat die titel van hierdie deel van die Liturgie is, kan daarin 'n aanduiding gevind word na watter fees verwys word. Ons kan aanneem dat die titel, 'Gebede van die fees van die agste dag/maand', na die fees waaraan die meeste aandag bestee word 
in die Liturgie, verwys. Daar bestaan twee moontlikhede vir die identifisering van die sewende fees wat in die Liturgie beskryf word. Die eerste moontlikheid is dat die fees wat beskryf word, die fees is wat op die agtste dag van die huttefees plaasvind (Rylaarsdam 1989:456). Dit is moontlik dat die fees wat die Liturgie beskryf, 'n vroeë tradisie van die gebeure is wat op die agste dag plaasgevind het. As die fees op die agste dag van die huttefees plaasvind, dus as die vierde fees van die sewende maand, sal die vergelyking wat die Liturgie tussen die vier feeste van die sewende maand en vier ander elemente tref, sinvol wees. Die tweede moontlikheid is dat die fees wat in die Liturgie beskryf word, verband hou met die fees wat beskryf word in 1 Konings 12:32-13:1. Volgens dié tradisie het koning Jerobeam van die Noordryk 'n aparte fees in die Noordryk ingestel wat in die agste maand gevier moes word. Jerobeam het geweet dat hy nie al die Israeliete kon keer om na Jerusalem te gaan tydens die feeste nie. As teenvoeter teen die huttefees wat in Jerusalem tydens die sewende maand plaasgevind het, het Jerobeam ' $n$ aparte fees in die Noorde in die agste maand ingestel. Die tweede moontlikheid is die waarskynlikste moontlikheid en wel om die volgende redes: Die Liturgie stel dat die koning van Israel sekere kultiese handelinge tydens die fees moes uitvoer. In die Noordryk het die koning die funksie van priester op homself geneem (Kraus 1966:152). Die Liturgie stel dat die ritueel by Bet-El uitgevoer moes word. Volgens 1 Konings 12 is die feesgebeure in die agste maand by Bet-El voltrek. Bet-El is gereken as die koninklike heiligdom van die Noordryk (1 Kon 12; Amos $7: 13$ ). By die fees wat die Liturgie beskryf, moes die koning ' $n$ mandjie met die eerstelinge van die oes bring. Die fees van insameling wat die afsluiting van die landboujaar was, het in die sewende maand plaasgevind. As teenvoeter kon die Noordryk die dankfees vir die oes uitgestel het tot die agste maand. Dit wil dus voorkom of die fees wat die Liturgie beskryf, verband hou met die fees van 1 Konings 12. Die Liturgie beskryf die feeste van Israel soos dit in ' $n$ ouer vorm bestaan het.

$\mathrm{Na}$ afloop van die bestudering van 'n deel van die Samaritaanse Liturgie, is dit duidelik dat daar uit die Liturgie inligting geput kan word wat kan help om die Pentateug beter te verstaan. Aangesien die Liturgie ongetwyfeld in sommige gevalle ' $n$ ouer tradisie as die Pentateug weerspieël, ' $n$ tradisie wat verlore gegaan het as gevolg. van Judese redaksiewerk, is die Liturgie van onskatbare waarde om tot kennis van die verhouding tussen Juda en Israel te kom.

\section{Literatuurverwysings}

Bowman, J 1977. Samaritan documents relating to their history, religion and life. Pittsburg Pennsylvania : Pickwick.

Brindle, WA 1984. Origin and history of the Samaritans. Grace Theological Journal 5, 47-75. 
Brown, S 1966. A critical edition and translation of the ancient Samaritan Defter (the Liturgy) and a comparison of it with early Jewish liturgy. Doctoral dissertation, University of Leeds.

Coggins, RJ 1968. The Old Testament and Samaritan origins. Annual of the Swedish Theological Institute 6, 35-48.

Cowley, A E (ed) 1909. The Samaritan Liturgy. Vol 2. Oxford: Clarendon.

De Vaux, R 1988. Ancient Israel, its life and institutions. London: Darton, Longman and Todd.

De Vries, SJ 1989. s v Calendar. IDB, Vol 1.

Elliger, K \& Rudolph, W 1984. Biblia Hebraica Stuttgartensia. Stuttgart: Deutsche Bibelgesellschaft.

Gaster, T H 1962. s v Samaritans. IDB, Vol 4.

Goldberg, PS 1957. Karaite Liturgy and its relation to synagogue worship. Manchester: University Press.

Heidenheim, M 1971. Bibliotheca Samaritana. Texte aus Samaria und Studien zum Samaritanismus. Amsterdam: Philo.

Jastrow, M 1967. Hebrew-Aramaic English dictionary. New York: P Shalom.

Kautzsch, E 1988. Gesenius' Hebrew Grammar. 2nd edition. Oxford: Oxford University Printing House.

Koehler, L \& Baumgartner, W 1958. Lexicon in Veteris Testamenti Libros. Leiden: E J Brill.

Kraus, H-J 1966. Worship in Israel. A cultic history of the Old Testament. Oxford: Blackwell.

Lisowsky, G 1958. Konkordanz zum Hebräischen Alten Testament. 2.Aufl. Stuttgart: Württembergische Bibelanstalt.

Maier, J 1972. Geschichte der Jüdische Religion. Berlyn: Walter de Gruyter.

Montgomery, JA 1968. The Samaritans, the earliest Jewish sect: Their history, theology and literature. New York: K T A V

Reed, W L 1989. s v Shechem. IDB, Vol 4.

Rylaarsdam, J C 1989. s v Booths, Feast of. IDB, Vol 1.

Venter, JGH 1989. Ontstaan van die Samaritane: 'n Kritiese herbesinning. HTS 45/1, 117-127.

Wintermute, O S 1989. s v Joseph son of Jacob. IDB, Vol 2. 